\title{
A Study of the Mechanisms by Which Adrenocorticotropic Hormone Maintains Adrenal Steroidogenic Responsiveness *
}

\author{
Robert L. Ney, Richard N. Dexter, Warren W. Davis, and \\ LEONARD D. GARREN \\ (From the Department of Medicine, Vanderbilt University, Nashville, Tennessee, the National \\ Heart Institute, Bethesda, Maryland, and the Department of Internal Medicine, \\ Yale University, New Haven, Connecticut)
}

\begin{abstract}
Following hypophysectomy in the rat, there was a progressive decline in the rate of adrenal protein synthesis in vivo during the ensuing 24$48 \mathrm{hr}$, and an accompanying decrease in the acute corticosterone secretory response to an intravenous injection of ACTH. There was a similar decrease in the in vitro conversion of $\Delta^{5}$-pregnenolone, progesterone, and deoxycorticosterone to corticosterone. These in vivo and in vitro effects of hypophysectomy could be reversed by the administration of depot ACTH for an additional $7 \mathrm{hr}$ period. However, if cycloheximide, an inhibitor of protein synthesis, was administered concomitantly with the depot ACTH, then the restorative actions of ACTH on the steroid biosynthetic pathway were prevented. These experiments suggest that ACTH maintains not only the general structure of the adrenal cortex, but also the level of the steroid biosynthetic mechanism, through its effects on adrenal protein synthesis.
\end{abstract}

\section{Introduction}

An intravenous injection of adrenocorticotropic hormone $(\mathrm{ACTH})^{1}$ causes an increase in adrenal corticosteroid secretion within minutes after its administration (1). The magnitude of this acute response is a function not only of the dose of

* Received for publication 26 May 1967 and in revised form 21 July 1967.

Presented in part at the national meeting of the American Federation for Clinical Research, 1 May 1966.

Supported by U. S. Public Health Service Grants 1RO1 AM 10134, 1 RO1 AM 10947, 9070-41-48818, and T1-AM-5092.

Address requests for reprints to Dr. Robert L. Ney, Department of Medicine, School of Medicine, University of North Carolina, Chapel Hill, N. C. 27514.

1 The following abbreviations and trivial names have been employed. ACTH, adrenocorticotrophic hormone; Cyclic AMP, adenosine-3', 5'-cyclic monophosphate; NADPH, dihydronicotinamide adenine dinucleotide phosphate; cholesterol, $\Delta^{5}$-cholesten- $3 \beta$-ol; $\Delta^{5}$-pregnenolone, $\Delta^{5}$-pregnene-3 $\beta$-ol-20-one; progesterone, $\Delta^{4}$-pregnene-3, 20-dione; deoxycorticosterone, 21-hydroxy- $\Delta^{4}$-pregnene-3, 20-dione; cycloheximide, 3-[2-(3,5-dimethyl-2-oxocyclohexyl)-2-hydroxyethyl] glutarimide.
ACTH injected, but also of the plasma levels of ACTH to which the adrenal glands have been chronically exposed for hours or days prior to the acute injection (1). The term "adrenal steroidogenic responsiveness" might be used to describe the latter effect. The diminished adrenal responsiveness in hypopituitarism (2) and the increased response in Cushing's disease (3) are examples of this phenomenon. In an experimental situation, adrenal steroidogenic responsiveness can be measured by determining the immediate increase in steroidogenesis resulting from the intravenous injection of a standard stimulating dose of ACTH. Whereas there have been a number of studies of the rapid stimulation of steroid production by ACTH, both with regard to the site in the steroid synthetic pathway that is stimulated and the mechanisms of the effect, less is known about the more chronic effect of ACTH to maintain the level of adrenal responsiveness. The present studies were therefore undertaken to study this latter process.

There is considerable evidence that the rapid 
stimulation of steroid biosynthesis following an acute injection of ACTH is primarily the result of an increased rate of conversion of cholesterol to $\Delta^{5}$-pregnenolone $(4,5)$. The $\Delta^{5}$-pregnenolone thus formed is converted in sequence to progesterone, deoxycorticosterone, and corticosterone by the rat adrenal, a process that is not influenced to a major degree by ACTH over short time intervals (5). The acute effect of ACTH can be blocked by a variety of inhibitors of protein synthesis (6-8). One of these inhibitors, cycloheximide, has been shown to block the increased conversion of cholesterol to $\Delta^{5}$-pregnenolone which is brought about acutely by ACTH (9). The adrenal conversion of $\Delta^{5}$-pregnenolone to corticosterone, which is relatively insensitive to ACTH over short time intervals (5), is not inhibited by cycloheximide over similar time intervals (7). Since total adrenal protein synthesis does not measurably increase during the short period of ACTH administration required for the rapid stimulation of steroidogenesis (7), it has been postulated that this acute effect of ACTH involves synthesis of a relatively specific protein fraction that plays a role in the control of steroidogenesis.

An effect of ACTH to increase total adrenal protein synthesis is demonstrable, however, when the hormone is given over longer time intervals (hours to days) (10-12). In the present experiments, we have explored the possibility that, as ACTH increases total adrenal protein synthesis for many hours, there might be an increase in enzymatic activity of the steroid biosynthetic pathway, including points additional to the site involved in the rapid stimulation of steroidogenesis. We have also considered the possibility that such effects might provide an explanation for the more chronic effect of ACTH to maintain the level of adrenal steroidogenic responsiveness. To study these questions, rats were hypophysectomized and examined for subsequent changes in adrenal protein synthesis, for changes in the corticosterone secretory response to a rapid intravenous injection of $\mathrm{ACTH}$, and for changes in the in vitro ability of adrenals to convert $\Delta^{5}$-pregnenolone, progesterone, and deoxycorticosterone to corticosterone (thereby testing segments of the steroid biosynthetic pathway not acutely stimulated by ACTH). The reversal of these changes by longacting depot ACTH has also been examined. In view of the knowledge that the acute effect of $\mathrm{ACTH}$ on steroidogenesis is blocked by inhibitors of protein synthesis, experiments have been performed to determine whether the long-term effects of ACTH on the activity of the pathway might also be modified by an inhibitor of protein synthesis.

\section{Methods}

Male Holtzman rats weighing approximately $200 \mathrm{~g}$ were employed in these experiments. Hypophysectomy was performed by the transaural method (1). $10 \mathrm{U}$ of zinc ACTH ${ }^{2}$ were administered subcutaneously when it was desired to achieve a sustained ACTH effect in the absence of the pituitary.

The acute steroidogenic response to ACTH was measured in the following manner. A maximally stimulating dose $(2 \mathrm{mU})$ of USP ACTH was injected into the femoral vein. Beginning $7 \mathrm{~min}$ later, the left adrenal venous effluent was collected for a 3 min period, and its content of corticosterone was measured. The methods for these procedures have been previously published (1).

Adrenal incubations were carried out according to the following protocol. Pairs of adrenal glands from individual animals were quartered and placed in $2 \mathrm{ml}$ of Krebs-Ringer bicarbonate buffer containing $200 \mathrm{mg}$ per $100 \mathrm{ml}$ of glucose. Preincubation was carried out for $30 \mathrm{~min}$, after which the medium was aspirated and discarded. $2 \mathrm{ml}$ of fresh medium was then added with appropriate additions (steroids, ACTH) for a $2 \mathrm{hr}$ incubation. The preincubation and incubation were carried out in a water bath with shaking, under an atmosphere of $95 \% \mathrm{O}_{2}-5 \% \mathrm{CO}_{2}$, at $37^{\circ} \mathrm{C}$. At the conclusion of the incubation, the glands were homogenized in the medium, and corticosterone was measured in the homogenate by the fluorescence method of Silber et al. (13). $\Delta^{5}$-Pregnenolone, progesterone, and deoxycorticosterone were added to incubations in $20 \mu \mathrm{l}$ of ethanol, providing concentrations of the steroids in the incubation medium ranging from 5 to $100 \mu \mathrm{g} / \mathrm{ml}$. These quantities of added steroids were not themselves detectable by the fluorescence method used for measuring corticosterone. ACTH powder was dissolved in $0.25 \mathrm{ml}$ of buffer for addition

2 Materials were obtained as follows : Zinc ACTH was obtained as cortrophin zinc from Organon Inc., W. Orange, N. J. ; ACTH powder utilized in incubations was obtained from Parke, Davis \& Co., Detroit, Mich.; USP ACTH utilized for intravenous injections was obtained from the U. S. Pharmacopeia, New York, N. Y.; $\Delta^{\mathrm{s}}$ pregnenolone, progesterone, and deoxycorticosterone were obtained from Mann Research Laboratories, New York, N. Y.; cycloheximide was generously provided by the Cancer Chemotherapy Branch, National Service Center, National Institutes of Health, Bethesda, Md.; ${ }^{10} \mathrm{C}$-algal protein hydrolysate was obtained from New England Nuclear Corp., Boston, Mass. 


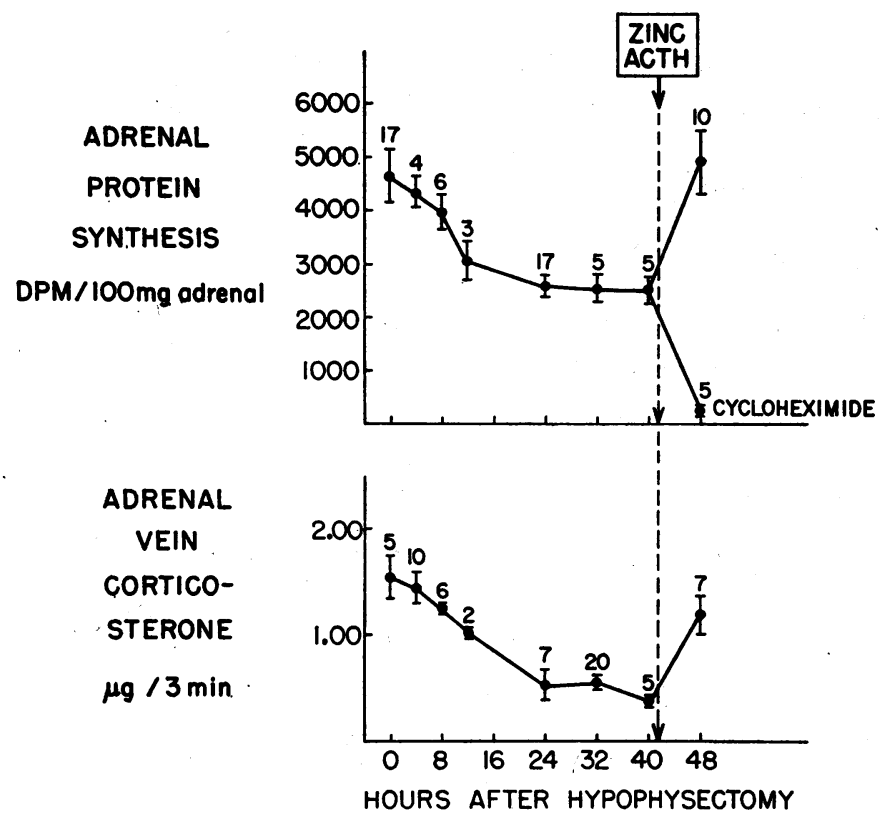

Fig. 1. EFFECTS OF HYPOPHYSECTOMY AND OF DEPOT ACTH ON ADRENAL PROTEIN SYNTHESIS AND STEROIDOGENIC RESPONSIVENESS IN vivo. The rate of adrenal protein synthesis, and the corticosterone secretory response to an intravenous injection of $2 \mathrm{mU}$ of ACTH was studied at varying time intervals after hypophysectomy in rats. A group of animals was given $10 \mathrm{U}$ of zinc ACTH subcutaneously $41 \mathrm{hr}$ after hypophysectomy, and these animals were studied $7 \mathrm{hr}$ later. An additional group of animals was given 10 $\mathrm{mg}$ of cycloheximide intraperitoneally just prior to zinc ACTH $41 \mathrm{hr}$ after hypophysectomy, and protein synthesis was studied in these animals $7 \mathrm{hr}$ later. In this and the following Figures, the points indicate the mean, the vertical bars the standard error of the mean, and the numbers above the bars, the number of observations at each point.

to appropriate incubation flasks, providing an ACTH activity of $2.5 \mathrm{U} / \mathrm{ml}$.

Adrenal protein synthesis was measured by injecting 4 $\mu \mathrm{C}$ of ${ }^{14} \mathrm{C}$-algal protein hydrolysate, intravenously. Adrenals were removed $10 \mathrm{~min}$ later, and incorporation of the labeled amino acids into protein was determined as previously described (7). Cycloheximide, $10 \mathrm{mg}$ in $1 \mathrm{ml}$ of $0.9 \%$ saline, was administered intraperitoneally in order to inhibit adrenal protein synthesis (7).

\section{Results}

Effects of hypophysectomy and of depot ACTH on adrenal protein synthesis (Fig. 1). The incorporation of ${ }^{14} \mathrm{C}$-amino acids into protein was utilized as a measure of adrenal protein synthesis. It should be noted, however, that the rate of incorporation of labeled precursors into protein could also be influenced by changes in amino acid pool sizes. The incorporation decreased progressively to a value of about $60 \%$ of the control by $24 \mathrm{hr}$ after hypophysectomy, and thereafter remained at this low level. When hypophysectomized animals were treated with $10 \mathrm{U}$ of zinc $\mathrm{ACTH}$, the incorporation of amino acids was restored to control levels within a $7 \mathrm{hr}$ period. These results are in agreement with previous experiments in which the chronic administration of ACTH to intact rats resulted in increased incorporation into adrenal protein of labeled amino acids administered in vivo (12). Similarly, when adrenals were removed from chronically ACTHtreated animals and cell-free preparations of these adrenals were incubated with labeled amino acids, the incorporation of the amino acids into protein was increased $(10,11)$. In addition to an in- 
creased rate of amino acid incorporation, ACTH has also been shown to increase adrenal protein content $(10,11)$.

Effects of hypophysectomy and of depot ACTH on the corticosterone secretory response to a rapid intravenous ACTH injection (Fig. 1). The adrenal corticosterone secretory response to a rapid intravenous injection of $2 \mathrm{mU}$ of ACTH also decreased progressively over a $24 \mathrm{hr}$ period after hypophysectomy, and thereafter remained at low levels. Treatment of hypophysectomized rats with $10 \mathrm{U}$ of zinc ACTH resulted in a return of the secretory response toward control values within $7 \mathrm{hr}$. A maximally stimulating dose of $2 \mathrm{mU}$ $\mathrm{ACTH}$ (1) was selected for the intravenous injections in order to provide a uniform test of adrenal responsiveness. With smaller doses, ACTH absorbed from depot injections of zinc ACTH might have been additive with the intravenous $\mathrm{ACTH}$ injection, thereby resulting in lack of uniformity in the test of adrenal response in the different experimental groups.

Effects of hypophysectomy and of depot ACTH on the subsequent in vitro responses of adrenals to $A C T H$. Corticosterone production was tested in vitro, utilizing adrenals from animals that were either intact, or hypophysectomized, or hypophysectomized and treated with depot ACTH. When adrenals were incubated without added ACTH or steroid precursors, the adrenals from control animals produced approximately $4 \mu \mathrm{g}$ corticosterone per $100 \mathrm{mg}$ adrenal tissue per $\mathrm{hr}$, while those from $48 \mathrm{hr}$ hypophysectomized animals produced $3 \mu \mathrm{g}$, and those from animals that were hypophysectomized $48 \mathrm{hr}$ and given zinc ACTH 7 hr prior to sacrifice produced about $5 \mu \mathrm{g}$. (Note data for incubations without additions in Fig. 3.) These relatively small differences might have been due to increased levels of corticosterone or corticosterone precursors formed in vivo in the control and depot ACTH-treated groups which were carried over into the incubations, or to circulating ACTH which was carried over into the incubations in these groups. It is evident, however, that if either or both of these factors were operating, it did not exert a major influence on the in vitro experiments.

The pattern of responses of the adrenals to maximally stimulating doses of ACTH in vitro (14) paralleled the pattern of responses observed

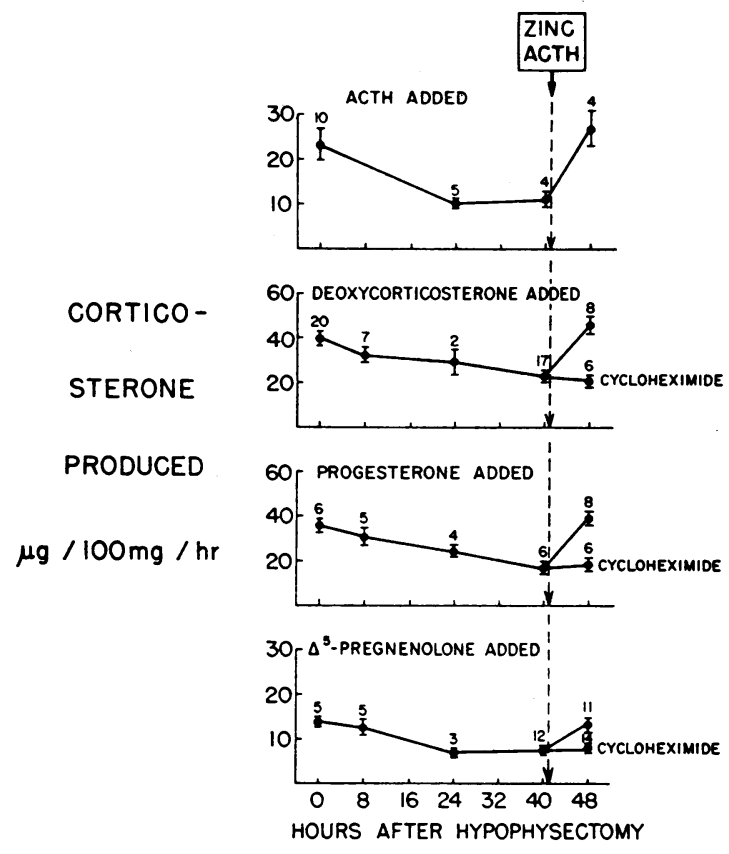

FIG. 2. EFFECTS OF HYPOPHYSECTOMY AND OF DEPOT ACTH ON THE SUBSEQUENT IN VITRO CAPACITY OF ADRENALS TO RESPOND TO ACTH AND TO CONVERT PRECURSORS TO CORTICOSTERONE. Adrenals were removed from rats at varying time intervals after hypophysectomy, and incubated with $2.5 \mathrm{U} / \mathrm{ml}$ of ACTH, or with $50 \mu \mathrm{g} / \mathrm{ml}$ of $\Delta^{\mathrm{s}}$-pregnenolone, or progesterone, or deoxycorticosterone. A group of animals was given zinc ACTH $10 \mathrm{U}$ subcutaneously $41 \mathrm{hr}$ after hypophysectomy, and their adrenals removed for incubation $7 \mathrm{hr}$ later. Some of the latter group of animals were also given $10 \mathrm{mg}$ of cycloheximide intraperitoneally just prior to the zinc ACTH injection.

in vivo. Thus, the in vitro responses to ACTH were markedly reduced when adrenals were removed from rats $24 \mathrm{hr}$ or more after hypophysectomy (Fig. 2). Furthermore, when hypophysectomized rats were given zinc ACTH $7 \mathrm{hr}$ before sacrifice, the subsequent in vitro responses to ACTH were restored to normal.

Studies on the activity of the steroid biosynthetic pathway between $\Delta^{5}$-pregnenolone and corticosterone. The in vitro capacity of adrenals to convert exogenous $\Delta^{5}$-pregnenolone, or progesterone, or deoxycorticosterone to corticosterone decreased progressively when the glands were tested at progressively greater time intervals after hypophysectomy (Fig. 2). The capacity to convert these precursors to corticosterone was restored to control levels when the hypophysectomized rats were given an injection of zinc ACTH $7 \mathrm{hr}$ prior to 


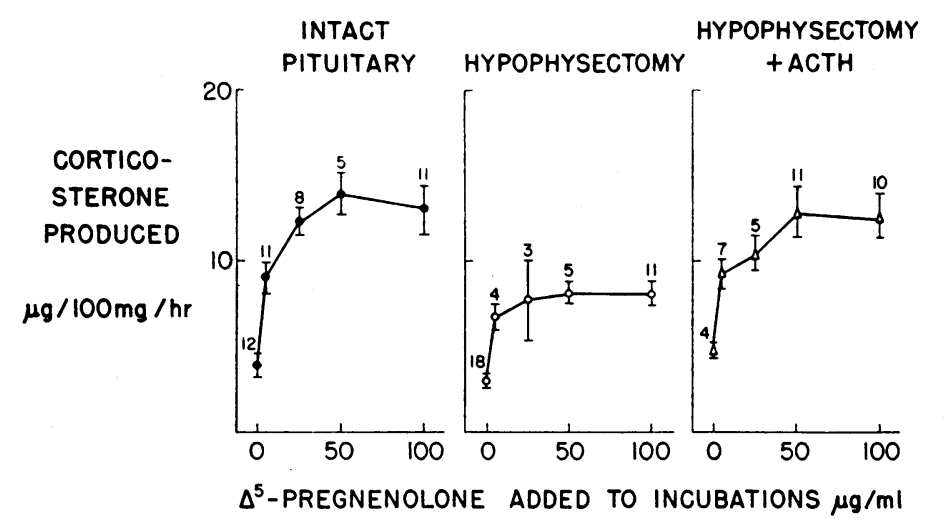

Fig. 3. EFFECTS OF HYPOPHYSECTOMY AND OF DEPOT ACTH ON THE SUBSEQUENT IN VITRO CAPACITY OF ADRENALS TO CONVERT $\Delta^{5}$-PREGNENOLONE TO CORTICOSTERONE. Adrenals were removed from rats either with intact pituitaries, or hypophysectomized $48 \mathrm{hr}$ previously, or hypophysectomized $48 \mathrm{hr}$ and injected with $10 \mathrm{U}$ of zinc ACTH subcutaneously $7 \mathrm{hr}$ before sacrifice. The glands were incubated in a medium containing no additions, or $\Delta^{5}$-pregnenolone in concentrations of $5,25,50$, or $100 \mu \mathrm{g} / \mathrm{ml}$, and the corticosterone produced was measured.

sacrifice. The decreased activity of the steroid pathway in adrenals from hypophysectomized rats and its restoration to control levels by zinc ACTH pretreatment of hypophysectomized animals was evident when a wide concentration range of each of the added precursors was tested (Figs. 3-5).

It seemed possible that the more chronic effect of ACTH to increase the activity of the steroid pathway between $\Delta^{5}$-pregnenolone and corticoster- one was induced by increased quantities of steroid substrates resulting from the known rapid action of $\mathrm{ACTH}$ to increase the formation of $\Delta^{5}$-pregnenolone from cholesterol (5). To test this question, animals were treated with amino-glutethimide, which has been shown to block the increased conversion of cholesterol to $\Delta^{5}$-pregnenolone brought about by ACTH, but not to modify the conversion of $\Delta^{5}$-pregnenolone to corticosterone (15). It was

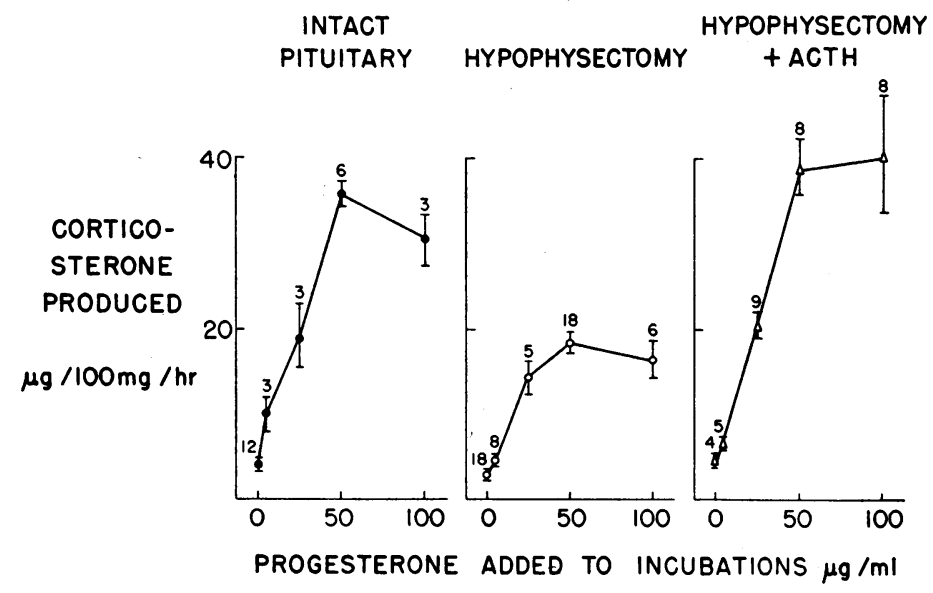

Fig. 4. EFFECTS OF HYPOPHYSECTOMY AND OF DEPOT ACTH ON THE SUBSEQUENT IN VITRO CAPACITY OF ADRENALS TO CONVERT PROGESTERONE TO CORTICOSTERONE. The experimental protocol was the same as that detailed for Fig. 3, except that progesterone was the precursor utilized in the experiments shown here. 


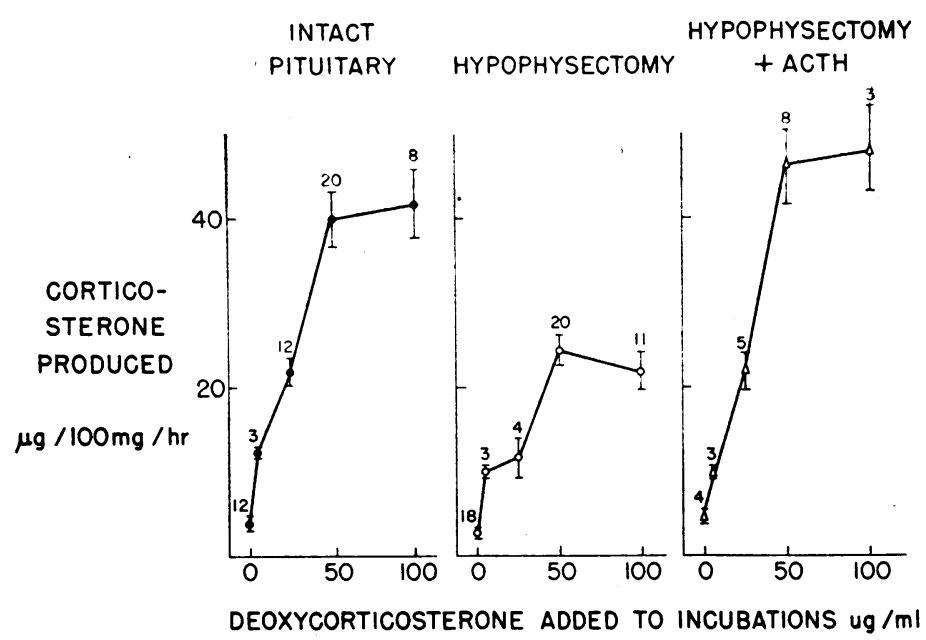

Fig. 5. EFFECTS OF HYPOPHYSECTOMY AND OF DEPOT ACTH ON THE SUBSEQUENT IN VITRO CAPACITY OF ADRENALS TO CONVERT DEOXYCORTICOSTERONE TO CORTICOSTERONE. The experimental protocol was the same as that detailed for Fig. 3, except that deoxycorticosterone was the precursor utilized in the experiments shown here.

then determined whether ACTH could still increase the activity of the steroid pathway between $\Delta^{5}$-pregnenolone and corticosterone at a time when little $\Delta^{5}$-pregnenolone would be formed. Adrenals were removed from rats $48 \mathrm{hr}$ after hypophysectomy and incubated with $50 \mu \mathrm{g} / \mathrm{ml}$ of deoxycorticosterone. When the hypophysectomized animals received no treatment, the adrenals produced $24.4 \pm 1.7 \mu \mathrm{g}$ of corticosterone $/ 100 \mathrm{mg}$ of tissue per hour (mean \pm SEM, 20 animals). When the animals received $10 \mathrm{U}$ of zinc ACTH $7 \mathrm{hr}$ before sacrifice, the adrenals produced $45.8 \pm 4.3 \mu \mathrm{g}$ of corticosterone ( 8 animals), and when the rats received $20 \mathrm{mg}$ of amino-glutethimide phosphate subcutaneously just prior to the ACTH injection, the adrenals produced $43.1 \pm 7.3 \mu \mathrm{g}$ of corticosterone (5 animals), representing a significant increase $(P<0.001)$ over the untreated hypophysectomized animals. ACTH thus increased the activity of adrenals in converting deoxycorticosterone to corticosterone at a time when little endogenous substrate was being formed, suggesting that the effect of ACTH on the later steps of the steroid pathway was not substrate induced.

Effect of an inhibitor of protein synthesis on the ACTH-induced increase in the activity of the steroid pathway. It was noteworthy that the decrease in adrenal protein synthesis after hypophysectomy and its restoration to normal by long-acting ACTH was accompanied by similar changes in the level of the steroidogenic response to $\mathrm{ACTH}$ in vivo and in vitro, and in the activity of the steroid biosynthetic pathway between $\Delta^{5}$ pregnenolone and corticosterone. It was possible that these represented only parallel but unrelated effects of ACTH. Alternatively, the ACTHinduced increases in the activity of the pathway might depend upon an increase in protein synthesis. To test the latter hypothesis, an experimental approach was employed which involved inhibiting adrenal protein synthesis with cycloheximide, and determining whether or not ACTH treatment would still result in an acceleration of the conversion of precursors to corticosterone. It has previously been shown that cycloheximide is rapidly effective in inhibiting adrenal protein synthesis (7), and in the present experiments it was found that this inhibitory effect was still present $7 \mathrm{hr}$ after an intraperitoneal injection of $10 \mathrm{mg}$ of cycloheximide (Fig. 1).

Before determining whether or not cycloheximide blocks the effect of ACTH to accelerate the conversion of precursors to corticosterone, it was important to determine whether cycloheximide itself modifies the steroid conversions. Such an inhibitory effect of cycloheximide could obscure a stimulatory influence on ACTH. Furthermore, cycloheximide exerts toxic effects in the doses 
TABLE I

Effects of cycloheximide on the conversion of precursors to corticosterone

\begin{tabular}{|c|c|c|}
\hline \multirow[b]{2}{*}{ Precursor added } & \multicolumn{2}{|c|}{ Corticosterone produced } \\
\hline & Hypophysectomy & $\begin{array}{c}\text { Hypophysectomy } \\
\text { cycloheximide }\end{array}$ \\
\hline & \multicolumn{2}{|c|}{$\mu \mathrm{g} / 100 \mathrm{mg}$ of adrenals $/ \mathrm{hr}$} \\
\hline $\begin{array}{l}\Delta^{5} \text {-Pregnenolone } \\
\text { Progesterone } \\
\text { Deoxycorticosterone }\end{array}$ & $\begin{array}{l}12.7 \pm 1.9^{*}(5) \\
30.5 \pm 3.8 \text { (5) } \\
32.4 \pm 3.6\end{array}$ & $\begin{array}{l}15.2 \pm 2.1(4) \\
36.1 \pm 6.9(5) \\
32.1 \pm 1.8(7)\end{array}$ \\
\hline
\end{tabular}

Rats were hypophysectomized, and some of the animals were given $10 \mathrm{mg}$ of cycloheximide intraperitoneally immediately thereafter. $7 \mathrm{hr}$ later, the adrenals were removed and incubated with a corticosterone percursor in a concentration of $50 \mu \mathrm{g} / \mathrm{ml}$. The corticosterone produced during the incubation was measured.

* Values are means \pm SEM. The number of animals in each group is shown in parentheses.

and treatment periods which were employed (16), and such effects might indirectly modify steroid biosynthesis. An experiment was therefore performed in which rats were hypophysectomized and divided into two groups; in one group each rat was given $10 \mathrm{mg}$ of cycloheximide intraperitoneally, whereas the rats in the other group were untreated. $7 \mathrm{hr}$ later the adrenals were removed from all animals, and incubated with $\Delta^{5}$-pregnenolone, or progesterone, or deoxycorticosterone. The conversion of these precursors to corticosterone was found to be similar in the two groups (Table I).

Whereas cycloheximide itself did not appear to impair the conversion of precursors to corticosterone, it did prevent the stimulatory effect of ACTH on these conversions. Thus, when cycloheximide was administered just prior to depot ACTH in hypophysectomized animals, the effect of ACTH to increase the activity of adrenals in converting $\Delta^{5}$-pregnenolone or progesterone, or deoxycorticosterone to corticosterone was prevented (Fig. 2).

\section{Discussion}

It has been shown previously that ACTH exerts a pronounced effect on total adrenal protein synthesis when it is given for periods of hours or days $(10-12)$. In the present experiments, this effect of ACTH was found to be accompanied by changes in the magnitude of the acute steroidogenic response to ACTH. Thus, after hypophysectomy of rats, the progressive decrease in adrenal protein synthesis was accompanied by a decrease in steroidogenic responsiveness to $\mathrm{ACTH}$, and both of these processes were restored to control levels by depot ACTH.

It was also found that the conversion of $\Delta^{5}$ pregnenolone, or progesterone, or deoxycorticosterone to corticosterone decreased progressively with time after hypophysectomy, and that these conversions were restored to control levels $7 \mathrm{hr}$ after the injection of depot ACTH. It cannot be stated whether a single or multiple points in the steroid pathway between $\Delta^{5}$-pregnenolone and corticosterone are affected in this long-term action of ACTH. It is clear that the last step (namely, the conversion of deoxycorticosterone to corticosterone) must be affected, but it is not yet established whether steps between $\Delta^{5}$-pregnenolone and deoxycorticosterone are also involved.

The chronic stimulating effect of ACTH on the steroid pathway was prevented when adrenal protein synthesis was blocked by cycloheximide. The interpretation of the experiments with cycloheximide is dependent on the assumption that the drug exerted its effects through its known inhibition of protein synthesis. It is possible that an as yet unrecognized action of the drug may be responsible for its inhibition of the ACTH-induced increase in the activity of the steroid pathway. With this reservation in mind, the experiments with cycloheximide can be viewed as an additional line of evidence in showing a relationship between the effects of ACTH on protein synthesis and on the activity of the steroid pathway. Since the present studies did not quantitate enzyme protein, it can only be suggested that the decrease in the activity of the steroid pathway which accompanies the decrease in protein synthesis after hypophysectomy may be due to diminution in the levels of the enzymes of the pathway.

In line with the present findings, Constantopoulos and Tchen, utilizing an enzyme preparation derived from adrenal mitochondria (17), have found that the activity of the desmolase complex, which converts cholesterol to $\Delta^{5}$-pregnenolone, also decreased with time after hypophysectomy along with the decrease in weight of the adrenals. ${ }^{3}$ The chronic administration of ACTH restored this enzymatic activity toward normal as the

\footnotetext{
${ }^{3}$ Personal communication from T. T. Tchen.
} 
adrenal cortex regenerated to its normal weight. Thus, the level of responsiveness of multiple portions of the steroidogenic pathway may be a function of the long-term trophic effect of ACTH. Even if one portion of the steroid pathway (presumably the conversion of cholesterol to $\Delta^{5}$ pregnenolone) were to remain rate-limiting for corticosterone synthesis at all times, it is of interest that ACTH exerts a chronic and more general effect to maintain the activity of multiple portions of the pathway. Therefore, when ACTH acutely activates steroidogenesis, presumably by a mechanism which activates the conversion of cholesterol to $\Delta^{5}$-pregnenolone, the level of the response is dependent upon the functional capacity of the entire pathway, and this in turn is dependent upon the more chronic influence of ACTH. The present studies would suggest that the levels of the enzyme proteins which make up the steroidogenic pathway may be dependent upon the presence of ACTH, just as the general protein structure of the hormone-responsive adrenal cortex is dependent upon ACTH (11). Of course, since each of the enzymes of the pathway are different proteins, it would not be surprising if their turnover rates were different. That is, after hypophysectomy, when adrenal protein synthesis decreases, the enzyme levels of the pathway could decrease at different rates and the return towards normal levels, after ACTH treatment, could also occur at different rates.

It is of interest that depot ACTH increased the rate of adrenal protein synthesis, the level of the corticosterone secretory response to an intravenous injection, and the activity of the steroid pathway in converting exogenous precursors to corticosterone within $7 \mathrm{hr}$, a time in which an increase in adrenal cell population is unlikely to have occurred (11). Thus, although an increase in cell number is eventually induced and undoubtedly plays a role in the long-term effect of ACTH to increase levels of steroidogenesis, there also appears to be a change in function per cellular unit of tissue.

The present studies suggest a mechanism for the changes in adrenal responsiveness in certain clinical states. Thus, the diminished rate of protein synthesis which occurs after hypophysectomy and its increase following the administration of ACTH may account for the hyporesponsiveness of the atrophic adrenals in hypopituitarism and the hyper-responsiveness of the hyperplastic glands in Cushing's disease.

\section{References}

1. Liddle, G. W., D. Island, and C. K. Meador. 1962. Normal and abnormal regulation of corticotropin secretion in man. Recent Prog. Hormone Res. 18: 125 .

2. Jenkins, D., P. H. Forsham, J. C. Laidlaw, W. J. Reddy, and G. W. Thorn. 1955. Use of ACTH in the diagnosis of adrenal cortical insufficiency. Am. J. Med. 18: 3.

3. Liddle, G. W. 1957. Cushing's Syndrome. In The Adrenal Cortex. A. Eisenstein, editor. Little, Brown and Co., New York. 523.

4. Stone, D., and O. Hechter. 1954. Studies on ACTH action in perfused bovine adrenals: The site of action of ACTH in corticosteroidogenesis. Arch. Biochem. 51 : 457.

5. Karaboyas, G. C., and S. B. Koritz. 1965. Identity of the site of action of $3^{\prime}, 5^{\prime}$-adenosine monophosphate and adrenocorticotropic hormone in corticosteroidogenesis in rat adrenal and beef adrenal cortex slices. Biochemistry. 4: 462.

6. Ferguson, J. J., Jr. 1963. Protein synthesis and adrenocorticotropin responsiveness. J. Biol. Chem. 238: 2754.

7. Garren, L. D., R. L. Ney, and W. W. Davis. 1965. Studies on the role of protein synthesis in the regulation of corticosterone production by adrenocorticotropic hormone in vivo. Proc. Natl. Acad. Sci. U. S. $53: 1443$.

8. Farese, R. V. 1964. Inhibition of the steroidogenic effect of ACTH and incorporation of amino acid into rat adrenal protein in vitro by chloramphenicol. Biochim. Biophys. Acta. 87: 699.

9. Davis, W. W., R. L. Ney, and L. D. Garren. 1966. Site of action of an inhibitor of protein synthesis which blocks the steroidogenic response to ACTH. Program of the 48th Meeting of the Endocrine Society. 61. (Abstr.)

10. Farese, R. V., and W. J. Reddy. 1963. Effect of adrenocorticotrophin on adrenal protein synthesis. Endocrinology. 73 : 294.

11. Farese, R. V. 1964. Changes in the ${ }^{14} \mathrm{C}$-glycine incorporating activities of rat adrenal microsomes and soluble cell fraction during prolonged adrenocorticotropin administration. Biochim. Biophys. Acta. $91: 515$.

12. Bransome, E. D., Jr., and W. J. Reddy. 1964. Incorporation of amino acids into rat adrenal protein in vivo: effects of adrenocorticotropin and growth hormone. Endocrinology. 74 : 495.

13. Silber, R. H., R. D. Busch, and R. Oslapas. 1958. Practical procedure for estimation of corticosterone or hydrocortisone. Clin. Chem. 4: 278. 
14. Saffran, M., and A. V. Schally. 1955. In vitro bioassay of corticotropin: Modification and statistical treatment. Endocrinology. 56: 523.

15. Dexter, R. N., L. M. Fishman, R. L. Ney, and G. W. Liddle. 1967. Inhibition of adrenal corticosteroid synthesis by amino-glutethimide: studies of the mechanism of action. J. Clin. Endocrinol. Metab. 27: 473.
16. Young, C. W., P. F. Robinson, and B. Sacktor. 1963. Inhibition of the synthesis of protein in intact animals by acetoxycloheximide and a metabolic derangement concomitant with this blockade. Biochem. Pharmacol. 12: 855.

17. Constantopoulos, G., and T. T. Tchen. 1961. Cleavage of cholesterol side chain by adrenal cortex: cofactor requirement and product of cleavage. $J$. Biol. Chem. 236: 65. 